Fandiño Parra, Y.J., Muñoz Barriga, A., López Díaz, R.A. y Galindo Cuesta, J.A. (2021). Teacher education and critical thinking: Systematizing theoretical perspectives and formative experiences in Latin America. Revista de Investigación Educativa, 39(1), 149-167.

DOI: http://dx.doi.org/10.6018/rie.416271

\title{
Teacher education and critical thinking: Systematizing theoretical perspectives and formative experiences in Latin America
}

\section{Formación docente y pensamiento crítico: sistematización de perspectivas teóricas y experiencias formativas en Latinoamérica}

\author{
Yamith José Fandiño Parra,Andrea Muñoz Barriga, Rodolfo Alberto López Díaz y Jairo Alberto \\ Galindo Cuesta \\ *Facultad de Ciencias de la Educación, Universidad de la Salle.
}

\begin{abstract}
Resumen
Dentro del marco teórico de la formación del profesorado y el pensamiento crítico, este trabajo de sistematización de experiencias formativas buscó rastrear tendencias e identificar perspectivas en Latinoamérica a través de la recolección de datos mediante dos etapas: revisión documental y análisis de una encuesta cualitativa en línea. Los resultados sugirieron que el enfoque cognitivo predominó en la conceptualización del pensamiento crítico, asumiéndolo como un proceso de adquisición y desarrollo de habilidades mentales a trabajar mediante una formación con enfoque crítico en la lectura y la escritura. No obstante, se observó una ausencia de propuestas que abordaran asuntos actitudinales, motivacionales y emocionales.

Palabras clave: formación del profesorado; pensamiento crítico; experiencias formativas; educación superior.
\end{abstract}

Correspondencia: Andrea Muñoz Barriga, andreamunozbarriga@gmail.com, Facultad de Ciencias de la Educación, Universidad de la Salle, Bogotá, Colombia. 


\begin{abstract}
Within the theoretical framework of teacher education and critical thinking, this work of systematization of educational experiences sought to track trends and identify perspectives in Latin America by collecting data through two different stages: a documentary review and the analysis of a qualitative online survey. The results suggested that the cognitive approach prevailed in the conceptualization of critical thinking, confirming that it is a process of acquisition and development of mental abilities, which could be developed through critical training in reading and writing. However, there was an absence of proposals that addressed attitudinal, motivational, and emotional issues.
\end{abstract}

Keywords: teacher education; critical thinking, formative experiences; higher education.

\title{
Introduction
}

Currently, there is a growing interest in doing research projects that qualify the education of both pre-service and in-service teachers. This interest has been driven by policies and diagnoses that place teacher education at the center of strategies and reforms aimed at improving and transforming educational systems (UNESCO, 2015; Fundación Compartir, 2014; OEI, 2013). At present, these new educational proposals regard teachers no longer as objects of change, but as subjects of change. In this regard, Torres (2000) states, "in order to change education, it is necessary to work with teachers, not against them or behind their backs, assuming them not only as agents of reform but as allies and as subjects of change "(p. 1).

Unfortunately, Vieira and Moreira (2008) argue that institutions such as ministries and faculties of education, still view teacher education as a way to show teachers procedures on what and how to do things (technical instruction) instead of providing them with tools and spaces to design their educational agendas and intervene decisively in their educational contexts (reflective research). It is important, then, to develop projects that legitimize teacher education as an educational and institutional perspective that favors critical reflection and research skills aimed at allowing teachers to develop comprehension and analysis as the basis for continuous improvement throughout their professional lives (Hargreaves, 1999).

On the other hand, the literature points out the importance of working with critical thinking, since it is seen as an important dimension of human development. This dimension covers the intellectual processes of conceptualizing, applying, analyzing, synthesizing, and/or evaluating information actively and skillfully. When processed critically through observation, reasoning and reflection, this information serves as a rational guide for action and belief (Scriven \& Paul, 2015).

That said, the relationship between teacher education and critical thinking appears to be indisputable since teachers are the first social actors expected to acquire and develop this type of thinking, which should inform their acting and speaking. This way, they can design and implement reflective and creative activities to infuse it into their students. From this perspective, Miranda (2003) states that the education of teachers in critical thinking enables them to: not only face their profession in a better way, but also make it easier for them to adapt to the changes that could occur in a work environment. Besides, critical 
thinking gives teachers a dynamic and predictive capacity that allows them to anticipate difficulties and problems as well as to organize strategies logically to solve them (p. 40).

Within this context, this paper reports on the findings of a research project carried out by a group of teacher educators at La Salle University. This project sought to systematize the nature and scope of educational experiences that teachers in Latin America have had when working with teacher education and critical thinking. In this sense, this study contributes to recognize patterns and trends present in some published academic sources and reconstruct perspectives and strategies used in classroom practices.

\section{Teacher education}

Teacher education accounts for both undergraduate and postgraduate programs that mark a continuous process of formal and non-formal experiences, aimed at the professional preparation of teachers (UNESCO, 1990). In this regard, Villegas-Reimers (2002) defines teacher education as a long-term process that includes eventualities and experiences programmed to foster growth and development in the profession. For Cochran-Smith and Zeichner (2009), teacher education takes place in communities and institutions, in which the components and structures of the programs interact, both with the experiences and skills teachers have and with the policies and conditions that governments impose.

Despite its conceptual richness, teacher education is experiencing a challenging moment, both in terms of initial teacher preparation and in terms of qualification of practicing teachers. Moreover, Rosemberg (2011) argues that there is a need to promote new and better educational processes because of the rapid changes in the world and the speed of knowledge production. These educational processes must transform traditional practices based on conceiving teachers as simple technicians that reiterate knowledge elaborated by others. Instead, these educational endeavors should redefine the role of teachers, "legitimizing and guaranteeing their place as active agents, producers of values and contents" (Rosemberg, 2011, p. 3).

From a critical approach, teacher education should be based primarily on trust in teachers, in the institutions where they work and in the educational communities in which they live. In this way, teacher education must follow principles that guide the learning practices of teaching communities to foster cooperation and shared expertise. Teacher education must, then, be understood as a professional commitment within the work of teachers to achieve the objectives of their profession while responding to the educational needs of their institutions and communities (Díaz-Maggioli, 2004).

Consequently, it is important that faculties of education and teacher education programs view their activities and spaces for teacher education as lifelong learning, in which teachers voluntarily devote themselves to studying the best ways both to articulate their teaching to the interests of their students and to redirect their actions towards the goals of their communities and institutions. This voluntary learning is an ongoing process of personal self-revelation, professional reflection and community growth that seeks to create and maintain communities of practice, alive and committed to its collective development. 
Considering the above, La Salle University views teacher education as a set of educational processes that enhances professional development in the creation of teaching experiences characterized by competent, autonomous, and committed professional performance (University of La Salle, 2007). Accordingly, La Salle University advocates for the design and implementation of educational programs aimed at promoting the reflection of teachers both on their practice and on topics of interest related to better learning. In such educational programs, discussion and exchange should be set up in such a way that they allow teachers to be empowered thanks to their actions and reflections (University of La Salle, 2010). Overall, teacher education should promote the construction of professional identities and learning paths based on reflective, transformative, and critical thinking.

\section{Critical thinking}

Undoubtedly, all human beings think, but they are not always consistent with their thinking and are even less aware of their own thinking processes. As a result, they usually make decisions without considering the data they may lack, or allow themselves to be influenced by prejudices and previous beliefs, or if they rely on erroneous grounds beyond the evidence of facts, the reflection of possible options and the argument of reasoning itself. In this regard, Elder and Paul (2008) argue "we need to reflect on our thinking and at the same time think about how to improve it" (p. 14).

Furthermore, the information and knowledge society impose a dually challenge for people. On one hand, most of the jobs and occupations involve tracking, processing, and analyzing information from different sources and in different modalities: textual, visual, sound, multimedia, etc. On the other hand, many of the processes and practices related to information and knowledge have been transferred to the Internet, databases, media, and social networks, in which reliability and validity become uncertain. To face this double challenge, it is important to teach critical thinking, which entails, among other things, making informed judgments, verifying the quality of information, explaining correctly and orderly and thinking autonomously.

In education, critical thinking is understood as "processes, strategies, and representations that people use to solve problems, make decisions, and learn new concepts (Sternberg, 1986, p. 13). To Enis (2001), critical thinking is a complex cognitive process that involves dispositions and capacities with three basic dimensions: logic (judging, relating words to sentences), criterial (using opinions to judge sentences) and pragmatic (understanding of judgment and the decision to build and transform the environment). For his part, Facione (2007) maintains that critical thinking is "the process of intentional self-regulated judgment" (p. 22). This process involves taking six steps, which are: (1) identifying a problem, (2) defining the context, (3) listing options, (4) analyzing reasons explicitly, (5) listing reasons explicitly, and (6) exercising self-regulation. As can be seen from these steps, critical thinking is an essential competence in life, which makes it possible to impregnate purpose, meaning and horizon to work, academic, social, cultural, and personal processes, practices, and experiences.

From a holistic perspective, Boisvert (2004) understands critical thinking as "the capacities and attitudes that play a leading role in the project of analyzing and mastering the 
innumerable information that characterize the current social context" (p. 25). As a result, this thinking entails acquiring skills and attitudes that enable people to decipher and simultaneously articulate various data and forms of information present in the spheres of social life: academia, work, communication, technology, etc. The author also argues that this type of thinking "occupies an important place in adult life, since it facilitates personal choices, the adoption of a lifestyle or the acquisition of material goods (Boisvert, 2004, p. 26). In this way, not only does critical thinking account for academic and scientific work, with issues such as logic, induction, deduction and reflection; but also it is part of people's daily lives by providing them with tools such as insight, ingenuity and foresight; tools that ultimately allow them to decide intelligently and act accordingly (Díaz \& Hernández (2002); Kegan (1994); Murray (2009); Limbach \& Waugh (2010, 2014); Webber (2012); Ledić (2006); Zohar \& Lustov (2018); Uribe et al. (2017)).

\section{Research Methodology}

The researchers opted for a qualitative descriptive study as they "seek to discover and understand a phenomenon, a process, or the perspectives and worldviews of the people involved... The use of a qualitative description approach is particularly relevant where information is required directly from those experiencing the phenomenon under investigation, where time and resources are limited and perhaps as part of a mixed methods approach" (Bradshaw et al., 2017, p. 1). Considering this, the researchers sought to gain insights from sources and informants to examine a complex phenomenon in its natural state, enabling theory and research design flexibility. As a result, comprehensive descriptive summaries and accurate details of the data collected were presented to facilitate readers' comprehension (Kim et al., 2018).

\section{Stage I}

\section{Design}

This stage involved a documentary review of 265 academic papers and theses, and the implementation of 137 qualitative surveys on critical thinking educational perspectives and experiences. For the first stage of the research, the literature review was carried out with 179 papers and 86 theses published between 2015 and 2017 in open databases such as Dialnet (C), Latindex (C), Redalyc (C) and Scielo (C). The papers and theses were discriminated by quantity and country of publication around four central themes: Cognition and critical thinking, teaching strategies and critical thinking, writing and critical thinking, and reading and critical thinking.

\section{Initial search}

In the documentary review, 380 academic sources were identified and uploaded into a shared folder on a free cloud storage. This identification followed three base inclusion criteria: types of texts (papers and theses), country of origin (Latin America), and year of publication $(2015-2017)$. 
Table 1

Academic sources reviewed in the first stage or moment of systematization.

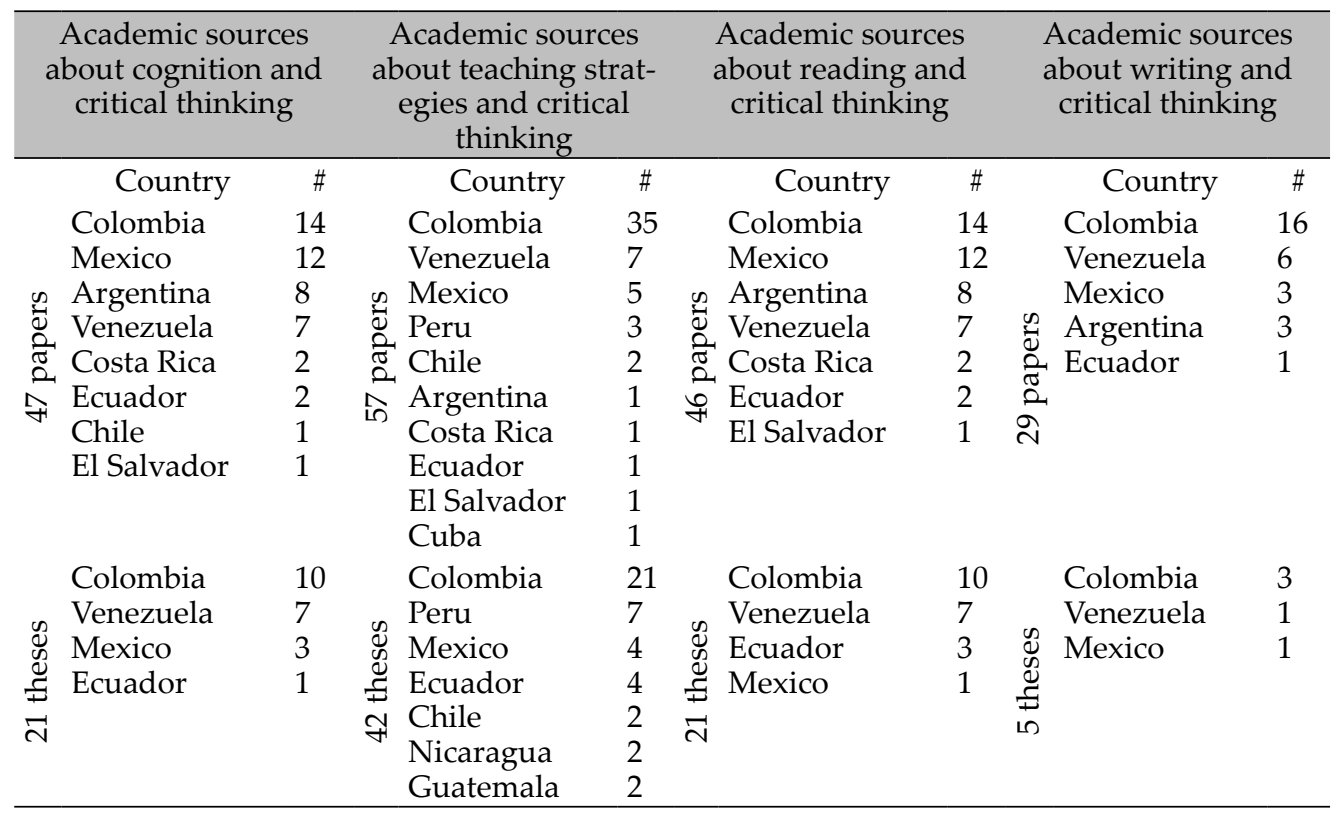

\section{Screening, inclusion and exclusion criteria}

Seven duplicate theses were removed and 20 papers with final publication dates before 2015 were also excluded. The remaining 353 papers and theses were screened by examining titles, abstracts, and full texts searching for four basic categories: cognition, teaching strategies, reading, and writing. The remaining 265 academic sources met inclusion criteria and comprised the sample for our systematic review.

\section{Full text analysis and final selection of studies}

In the qualitative online surveys, 211 subjects replied positively to our open call to participate in this stage following a purposive sampling method. Due to personal or work circumstances, 74 of them quit. The remaining 137 comprised our sample. Academically speaking, our sample consisted of mixed group of participants whose academic levels were as follows: undergraduate (29), specialization (11), master's degree (78), Ph.D. degree (13) and other (6). In relation to workplaces, they worked as teachers in public and private schools and universities in Colombia (54\%), Venezuela (39\%), Chile (4\%), and México, Aruba, and Brazil (1\%). Criteria such as gender, age, and race were not included as they did not seem to come into play and their use, in turn, may have brought about biases. See figures below. 


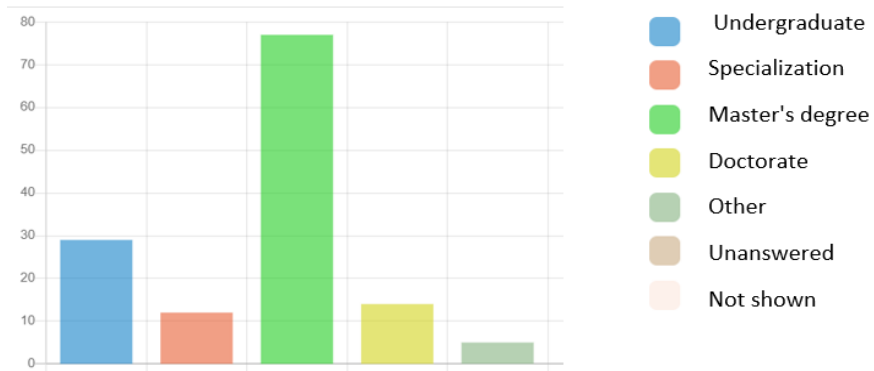

Figure 1. Data on the level of education of the population surveyed.

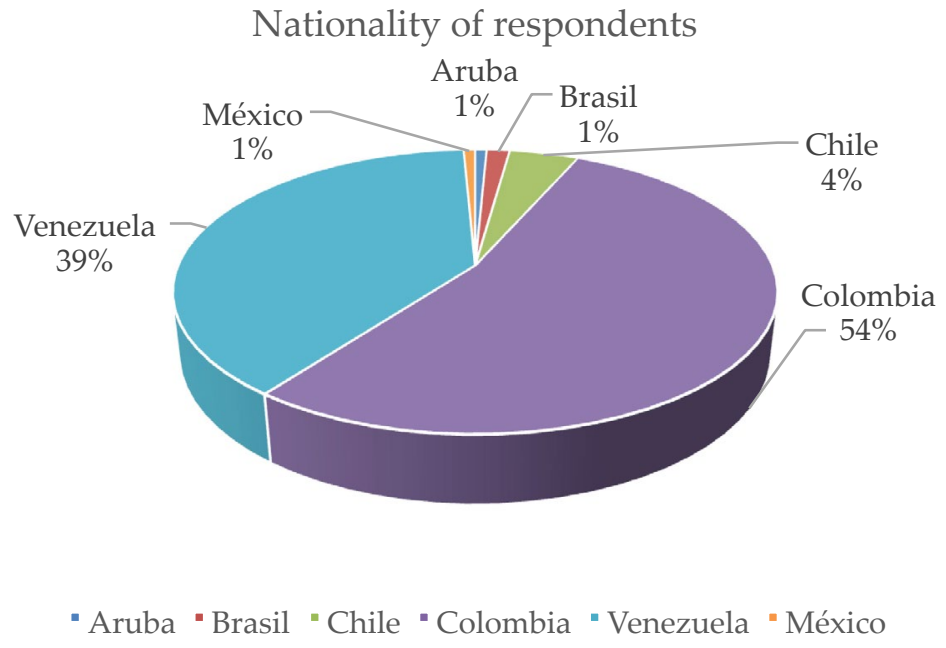

Figure 2. Nationality of respondents

The results of the literature review emerged from the application of four phases proposed by Londoño et al. (2014). The phases adopted were the following: a) contextualization: in this phase, the researchers carried out an initial bibliographic tracking process that allowed an initial identification of theses and research papers that reported teacher-led projects about teacher education and critical thinking (theses and research articles); b) classification: the researchers determined a set of parameters to be considered for the organization of the information to be analyzed. Some of these parameters were publication dates, objectives, methodologies, results, conclusions, and contributions of each investigation; c) categorization: the researchers hierarchized and grouped information for its correct processing. This hierarchy and grouping enabled the researchers to identify internal and external categories. The former derived directly from the systematic exploration of each of the predetermined parameters and the latter arose from the synthetic search of emergent issues or factors; and d) analysis: it con- 
sisted of establishing analytical associations of the internal and external categories in order to recognize patterns and trends present in the educational experiences reported in the consulted academic sources.

Because of the implementation of these phases, the researchers managed to recognize a co-occurrence of four patterns or trends among the reported educational experiences. These patterns or trends were a) the cognitive dimension of the formation of critical thinking, b) the teaching strategies involved in formation of critical thinking, c) reading in the formation of critical thinking and d) writing in the formation of critical thinking. The table below shows the number of papers and theses that discussed the four patterns or trends found in the literature review.

\section{Results}

\section{Cognitive dimension in the formation of critical thinking}

The literature review of theory-based experiences made it possible to discover that there is a research pattern or trend directed to the cognitive dimension of critical thinking, since several academic sources focused on determining the mental skills involved in its formation. In this trend, two debates tend to appear: (1) the differentiated or complementary teaching of basic cognitive skills and complex cognitive skills and (2) the work with specific cognitive skills for certain disciplinary areas and the work with common generic cognitive skills among different disciplines. Now, although there is no consensus on the sources consulted, it is possible to perceive that the formation of critical thinking is seen as a process in which the work with cognitive skills plays a significant role.

The category "process" is predominant in the conceptualization of critical thinking and it involves not only the development of certain cognitive skills linked to various fields of knowledge, but also the acquisition of attitudes such as open-mindedness and intellectual honesty. Such attitudes are decisive in thinking reflectively regarding problem solving. This means that, for the development of critical thinking, it is essential both to develop basic and complex mental skills and to enhance the individual's willingness to reflect logically.

Consequently, critical thinking involves not only the development of a set of cognitive skills of varying degrees of complexity, but also the acquisition of attitudinal and self-regulation processes. In this regard, a knowledge gap is perceived in the literature since research about the role of emotional and learning-related factors in critical thinking is limited. In other words, there is a marked propensity to work with the explicit teaching of thinking skills, which neglects the study of affective, attitudinal, and metacognitive components.

\section{Teaching strategies for the formation of critical thinking}

First, it is important to mention that the sources consulted suggest the use of coinstructional strategies, which are defined by Díaz and Hernández (2002) as strategies that support curriculum content during the teaching-learning process itself. They cover 
functions so that the learner improves attention and detects the main information, achieves better coding and conceptualization of the learning contents, and organizes, structures, and interrelates important ideas.

Some of the mentioned strategies are alternate questions, graphic organizers, analogies, concept maps, and textual structures. These strategies encourage learners to acquire and develop analysis, reflection, evaluation, and decision-making.

Secondly, in higher education, there is a trend in relation to the importance of decision making for social transformation in the development of critical thinking. This trend is evidenced through strategies focused on the generation of judgments with critical sense in spaces of inquiry for the resolution of social problems. The skills involved here range from observation and comparison to argumentation and counter-argumentation.

As a third trend, in basic and secondary education, it appears teachers give greater importance to the formation of intellectual abilities through the processing, understanding, and restructuring of information. Most activities revolve around working with different types of texts such as literary texts, journalistic texts, and academic texts. Activities range from the search of sources and the description of their contents to the use of synthesis and logical reasoning to assess the relevance and adequacy of texts.

\section{Reading in the formation of critical thinking}

First, it is important to mention that there is a marked pattern to diagnose reading levels and assess reading skills as a basis for the formation of critical thinking. In this sense, research focuses on inquiring about the basic and complex skills that are involved in the different levels of reading: literal, interpretive, comprehensive, and critical.

On that basis, a second trend appears to involve understanding critical reading as a process, which is consolidated through the development of basic and complex reading skills. On one hand, observation, description, comparison, and reflection are understood as basic skills needed to promote literal reading processes. These skills are to be developed in context through communicative interaction. On the other hand, the elaboration of inferences, associations, analogies, comparisons and recontextualizations are regarded as complex skills. Learners are encouraged to use these skills in activities oriented towards interpretation, understanding and critical reflection.

In addition, there is a third trend that views critical reading as a strategy that involves the development of a series of intentional steps, in which knowledge, skills and attitudes are articulated. It is worth noting here that in the literature, components related to the cognitive and metacognitive dimension of critical reading learning are predominant in the analysis. Although the attitudinal component is mentioned as a dimension of critical thinking, a few studies explore this dimension explicitly.

\section{Writing in the formation of critical thinking}

First, the literature review suggests there is a marked pattern to develop diagnoses of the levels of learners' textual production. Based on the results of those diagnoses, teachers tend to propose the teaching of writing to work with basic and complex cognitive skills, which will ultimately develop or promote critical thinking. On that 
basis, the teaching of writing and critical thinking involves the exercise of linguistic skills associated with textual comprehension and written production. This exercise is thought to promote not only the development of communicative competence, but also the development of intellect and logic.

A second trend evidences the emphasis on the use of teaching strategies and activities linked to the elaboration of different types of texts; concretely, these texts are informative, expository, and argumentative. Most experiences related to the work with journalistic texts, critical reviews, argumentative essays, and debates. However, school and university teachers appear to favor critical reviews and essays as the most effective tools to develop the basic and complex cognitive skills involved in critical thinking.

As a third trend, teachers seem to favor the inclusion of problem solving in writing tasks. They do so by resorting to instructional models focused on procedural writing. That is, teachers involve pre, during and post writing phases articulated with metacognitive activities and peer assessment processes.

\section{Stage 2}

\section{Participants}

For the second stage of the research, the qualitative surveys were applied to 137 teachers from 3 Latin American countries. They participated voluntarily upon a request on sharing their experiences in classroom projects and teacher interventions that dealt with critical thinking education.

Concerning the temporal dimension, the survey was transversal, since it collected information from a defined population during a limited period. In connection with the time that respondents referred to as reporting margin for their experience, the following results were obtained among the 137 respondents (Table 2).

Table 2

Statistics of analysis on the duration in months of the experience registered.

\begin{tabular}{lr}
\hline Standard deviation & 41,8 \\
Average & 25,37 \\
Minimum & 0 \\
First quartile (Q1) & 6 \\
Second quartile (Medium) & 12 \\
Third quartile (Q3) 24 & 24 \\
Maximum & 240 \\
\hline
\end{tabular}


The data showed that none of the experiences registered lasted less than 6 months, most of them lasted 2 years (25 months), and that 20 years records were found in the teaching work (240 months).

\section{Instruments}

Regarding the online survey, it was designed and piloted with the collaboration of fellow professors from the School of Education Sciences. Once validated, this one hour survey was made up of a set of 34 questions organized as follows:

- 11 questions on demographic data to characterize the defined population: postgraduate or training teachers, experience, and knowledge in critical reading topics.

- 15 questions about critical thinking in which we asked about the definition of critical thinking and its relationship to different levels of understanding (literal, inferential, and superior).

\section{Procedure}

A first set of questions asked the participating subjects for their level of agreement or disagreement regarding a series of perspectives related to critical thinking. These perspectives were determined under the following approaches: scientific, societal, functionalist, autonomist, judgmental, integrative, cognitive, socio-affective, philosophical and information management. For presentation and analysis purposes, these positions were valued and analyzed within a figure that allowed to attribute level of agreement for each value.

In the second set of questions, the methods and strategies implemented to promote critical thinking in relation to reading and writing in training practices were also investigated. This section of questions was completed by consulting the degree of importance of some characteristics for the development of critical thinking. Questions of the Likert type were asked about the relationship between teacher training and the presence of critical thinking in it. This section also consulted for the strategies that each teacher in training knew and implemented to promote critical thinking in education, particularly in the processes of reading and writing. It is important to highlight that both closed type questions (multiple choice, classification, and checkboxes) and open type questions (descriptions of opinions, experiences and learning) were used.

During this second stage, the researchers decided to carry out a systematization of two types of educational experiences. The former were experiences registered and distributed publicly through academic sources and the latter were experiences described and shared through qualitative online surveys. The researchers opted for the complementary use of these two types of experiences sought to overcome what Gravett (2012) called the theory-practice divide in teacher education. Such divide consists of an epistemological division that separates theory (formal, declarative knowledge as it appears in academic contexts) and practice (informal, procedural knowledge as it emerges in practical contexts) as if they were opposing concepts and realities. Instead, Gravett advocates for regarding theory and practice as two sides 
of the same coin as they are terms and dimensions that interact and interrelate in teacher education.

Concretely, the twofold nature of this systematization intended to recover, reconstruct, and communicate knowledge produced in theory and practice-based experiences, to turn them into consistent and sustained principles through critical and dialogical reflection (Torres, 1996). In this systematization, researchers viewed experience as their object of study, understanding it as a rich space in which knowledge emerges from the interaction and integration of (a) theoretical knowledge documented in academic sources and (b) practical knowledge gathered in qualitative online surveys. This way, the researchers conceived systematization as an interactive and integrative research loop (see figure 3) that combines the review of theoretical knowledge and the recovery of practical knowledge. As an interactive and integrative loop, systematization helped the researchers recognize patterns and trends as well as reconstruct perspectives and strategies that underlie educational experiences. Ultimately, this kind of interactive and integrative systematization can help researchers and teachers to guide future actions and decisions more adequately considering the theoretical and practical levels or aspects of their educational experiences (Barnechea \& Morgan, 2007).

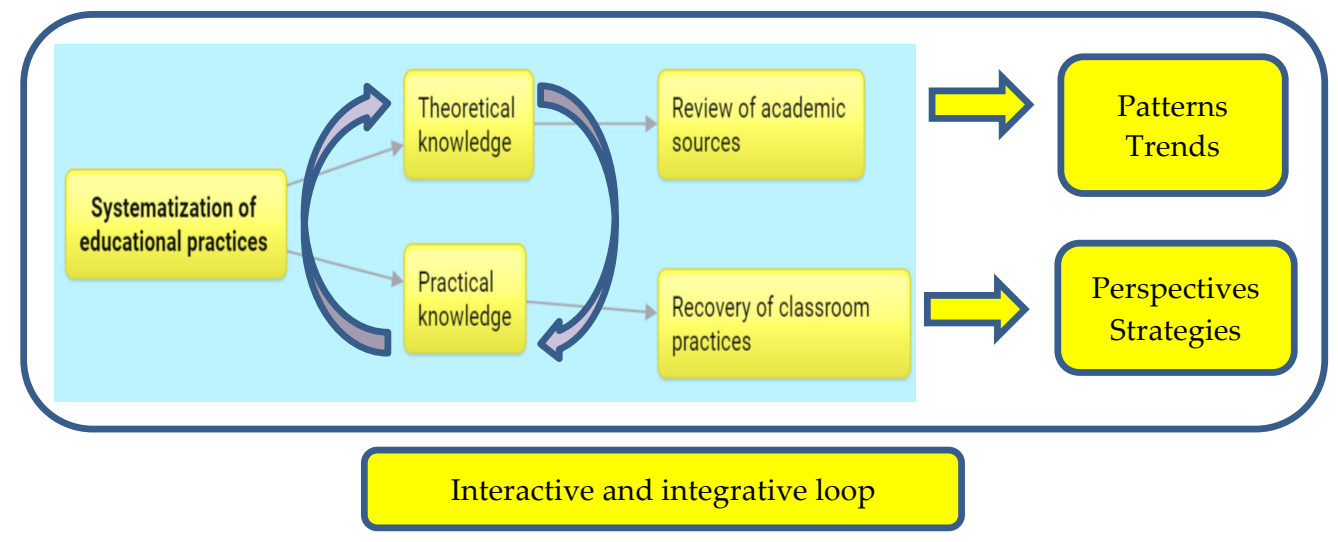

Figure 3. Research loop between review of theoretical knowledge and recovery of practical knowledge as basis for the systematization of educational experiences.

\section{Data analysis}

Qualitative data from open questions were gathered and analyzed on AtlasTi. Content analysis was used through the use of thematic or categorical analysis as a technique, which involved pre-analysis, material exploration, treatment of results, inference and interpretation. 


\section{Results}

The results allowed for the observations that the integrative and societal perspectives were those that had a better acceptance on the part of the respondents. In the same way, the philosophical and judgmental perspectives were those that received the lowest level of agreement among the participating population. In contrast, there were perspectives whose level appeared "balanced" according to the recorded results: functionalist, socio-affectivity, and information management. See figure 4 where results about the perspectives are synthesized.

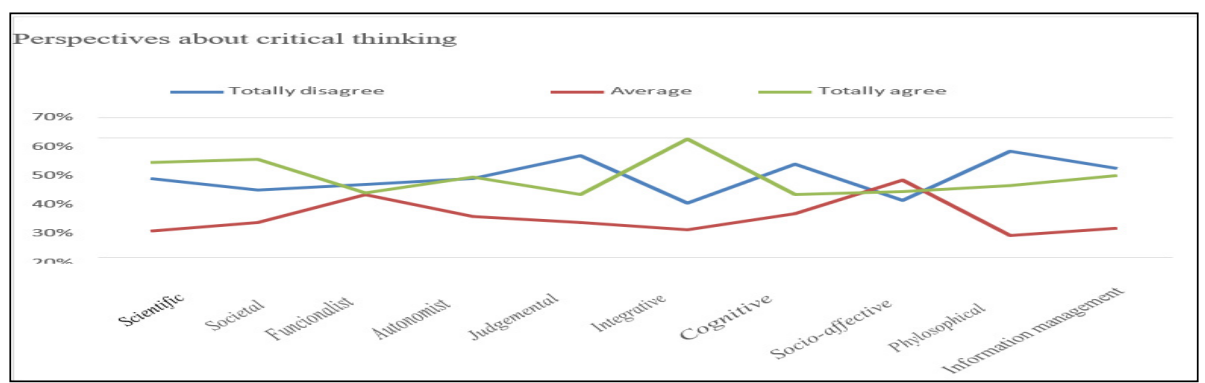

Figure 4. Synthesis of results about teachers' perspectives about teacher education and critical thinking.

The participants seemed to perceive critical thinking training as a resource that would allow them to acquire and develop a set of interrelated knowledge, skills and attitudes that allow teachers to understand and function successfully in their social contexts. Additionally, this kind of formation seems to enable teachers to become humanistic and emancipated members of their educational communities and collegiate groups. In other words, results suggest that developing all human dimensions interactively as well as becoming functional social actors are concerns teachers had when embarking on educational experiences and projects dealing with teacher education and critical thinking (Tamayo et al., 2015).

Now, contrary to the cognitive emphasis found in the reviewed papers and theses, results indicated teachers had moved from purely philosophical and judgement-based reasons or purposes as the basis for the formation of critical thinking. They seemed to be interested in exploring its potential in areas as varied as problem solving, information management, and socio-affective development. In other words, teachers chose to train in the development of critical thinking as a path to contribute to the integral education of people, education that involves considering the different dimensions of human and social development. Following Kegan (1994), Murray (2009) defines this education as self-authoring or co-creative learning, which enables learners "to examine themselves and their culture, develop critical thinking and individual initiative, and take responsibility for their learning and productivity" (p. 17). 


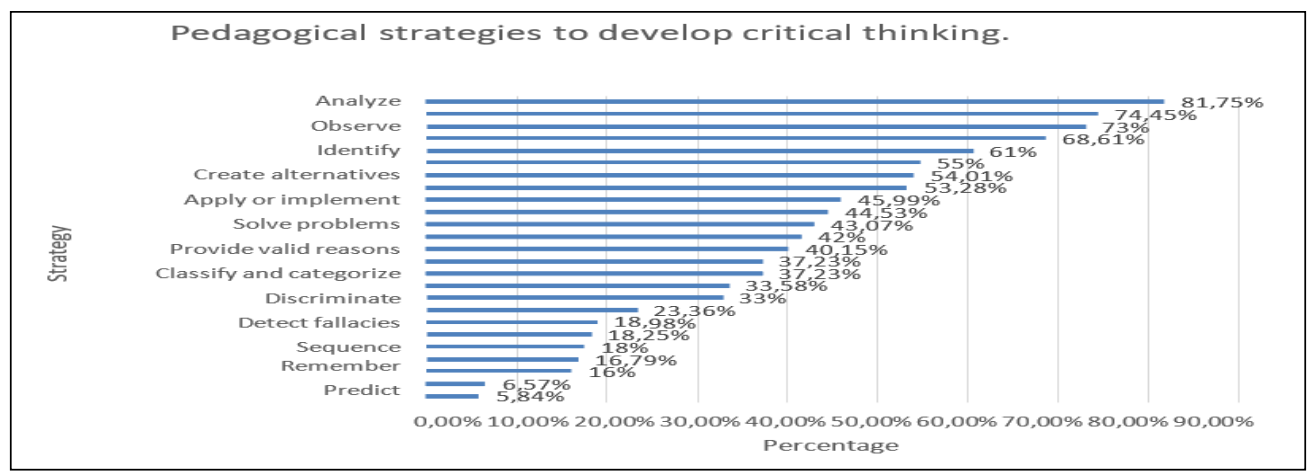

Figure 5. Pedagogical strategies to develop critical thinking.

A second set of questions asked the participating subjects for their opinions about a series of strategies or techniques related to critical thinking. These strategies were classified as pedagogical strategies or classroom techniques. For presentation and analytical purposes, these strategies were valued and analyzed within figures that allowed subjects to attribute percentages to each value. See figures below that synthesized results.

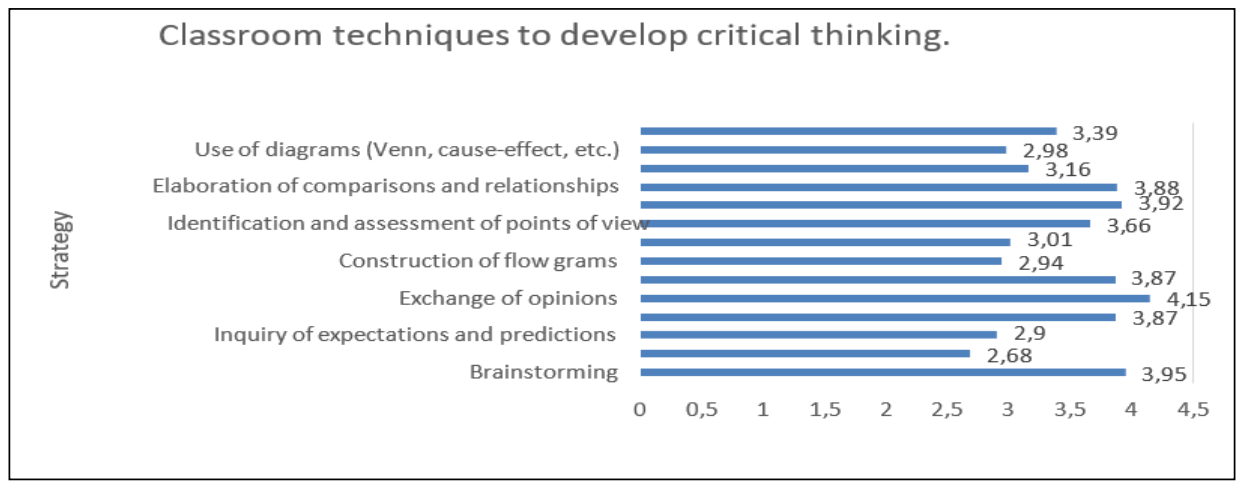

Figure 6. Classroom techniques to develop critical thinking.

Analyzing, observing, identifying, creating alternatives, applying, or implementing and solving problems were the instructional strategies most frequently used or promoted for the development of critical thinking. On the other hand, predicting, remembering, sequencing, detecting fallacies and discriminating were not such welcome actions when working with this area of teacher education. These results appeared to suggest teachers strive to focus their work on higher level thinking, which "allows people to excel and achieve intellectual freedom so that they can make sense of the world and positively impact the quality of their lives" (Limbach \& Waugh, 2010). Participants claimed this kind of thinking was relevant to our knowledge-based society, fast-paced world, and globalized job markets. Furthermore, they believed this thinking helped 
people "become independent and reflective lifelong learners who are able to function in a dynamic educational and professional environment" (Limbach \& Waugh, 2014).

In terms of classroom techniques, participants favored exchange of opinions, brainstorming, and identification and assessment of points of view. Construction of flowcharts, use of diagrams, and inquiry of expectations and predictions were less common. This may be related to the fact that the formative areas to which the respondents belonged were, for the most part, social sciences and not basic or exact sciences. As a result, they appeared to focus on activities where learners were actively engaged. They claimed these activities were aligned with the so-called learner-centered paradigm, which seeks to provide learners with learning environments where they acquire construct knowledge for themselves according to their own learning styles (Webber, 2012).

When exploring the frequency with which some class activities were carried out, five stood out: workshops, German seminars, forums, teacher-led discussions, and student-led presentations. Out of these activities, workshops and the German seminar tended to be associated with teacher education and critical thinking. Participants stated these activities enabled them to work with active learning, which is defined by Ledic (2006) as learning that enables students to have a high level of autonomy and self-monitoring, and to apply various mental strategies and specific cognitive skills to differentiate between important and unimportant information, analyze and compare, and construct new knowledge on the previous experiences and think critically (p. 60).

A combination of the findings shown above indicated that teachers were aware of the importance of carrying out projects and activities that combine teacher education and critical thinking strategically. However, it was necessary to incorporate metacognition and innovation, to help learners plan, monitor, and regulate specific actions in the creation and introduction of new ideas. This bifold work could help pre-service and in-service teachers acquire metastrategic knowledge and metacognitive skills. To Zohar and Lustov (2018), metastrategic knowledge "entails knowledge about what thinking strategies can accomplish, about when, why, and how to use these strategies, and about the goals and requirements of tasks" (p. 88) whereas metacognitive skills are "the skills and processes used to guide, monitor, control, and regulate cognition and learning" (p. 88).

\section{Discussion and conclusion}

In today's information and knowledge society, teacher education and critical thinking are topics of interest. On one hand, there is a growing need to understand how teacher cognition develops and identify which thought processes are part of it; both at the level of initial teacher training, and their continuing education once they are working. On the other hand, the urgency of understanding how teachers understand and practice the teaching of critical thinking in their classrooms is recognized. Specifically, it is seen as necessary to describe and analyze the perspectives and the strategies that they usually use in their academic spaces. Authors such as Solar and Díaz (2007) and Contreras (2008) advocate the realization of studies that account for both the development of teacher cognition and the teaching of critical thinking with the ultimate goal of hav- 
ing a conceptual framework that allows for establishing educational programs with qualified guidelines, activities and experiences.

Furthermore, it is vital that teachers explore and enact new theories of learning, alternative pedagogical theories, and innovative knowledge creation modalities in response to the perceived deficiencies of traditional and institutional education. Webber and Miller (2016) call these new, alternative and innovative methodologies "progressive pedagogies", which they define as "interdisciplinary, integrated, and inquiry-based perspectives, which take into account the context of learners and recognize the importance of experiential and holistic learning in community and place-based settings" (p. 1062). To them, schools of education and teacher education programs need to complement subject-specific content and methodologies with methods and approaches that "engage available resources and include diverse ways of learning, to be supple in responding to changing environments and educational needs, and to prepare students for lifelong learning and civic engagement" (p. 1074).

In connection to teachers' pedagogical strategies and classroom techniques, the researchers conclude that the use of exchanging opinions, brainstorming and assessment of viewpoints as well as the implementation of workshops and German seminars sought to promote active learning as well as autonomy and self-monitoring. By using these strategies and techniques, teachers strive to equip learners with a repertoire of knowledge, skills, and attitudes that allow them to challenge misjudgments and reconstruct their mental models based on accurate and logical understanding. In other words, teachers seek to attain higher levels of learning, resulting in improved comprehension and transfer of knowledge, skills and attitudes into practice and real life.

Nevertheless, it is imperative that teachers address metacognition and innovation in informed and systematic ways so that learners can deal with the complex and changing problems of today's world. This means teachers should work with critical thinking in teacher education, not just to help learners be active participants of their learning processes, but more importantly to become agents of social change, capable of moving towards action. Bourn (2016, p. 67) defined them as "people who are socially responsible and actors in securing change in both their own educational community and in wider society". In this perspective, Murray $(2009$, p. 9) advises schools of education and teacher education programs to work with meta-perspectives; approaches that "help learners develop higher level skills such as meta-cognition (thinking about thinking), meta-knowledge (knowledge about the nature and limitations of knowledge), meta-learning (learning how to learn), and meta-dialog (dialog about how we engage in interactions).

Undoubtedly, both theoretical knowledge and practical knowledge suggest that the co-joint work with teacher education and critical thinking enables the acquisition and development of knowledge, skills and attitudes needed for professional and everyday life. Nevertheless, this acquisition and development can be more effective and permanent when, as explained by Uribe et al. (2017), individuals become conscious of the needs of both their individual and social contexts and take advantage of opportunities for long-term growth without detriment to others. More importantly, this acquisition and development require pre-service and in-service teachers "to develop critical thinking skills which go beyond intellectual brilliance and capacity 
as they also embrace leadership, companionship, courage, creativity, perseverance, discipline, freedom, honesty, maturity, integrity, autonomy, transformation, discernment, and empathy" (Uribe et al., p. 85).

\section{References}

Barnechea, M., \& Morgan, M. (2010). La sistematización de experiencias producción de conocimientos desde y para la práctica. Revista Tendencias y Retos, 0(15), 97-107.

Boisvert, J. (2004). La formación del pensamiento crítico. Fondo de cultura económica.

Bourn, D. (2016). Teachers as agents of social change. International Journal of Development Education and Global Learning, 7(3), 63-77.

Bradshaw, C., Atkinson, S., \& Doody, O. (2017). Employing a Qualitative Description Approach in Health Care Research. Global Qualitative Nursing Research, 4(1), 1-8. doi.org/10.1177/2333393617742282

Cochran-Smith, M. \& Zeichner, K. (2009). Studying teacher education. The report of the AERA panel on research and teacher education. Lawrence Erlbaum Associates Publishers.

Contreras, S. (2008). Qué piensan los profesores sobre sus clases: Estudio sobre las creencias curriculares y las creencias de actuación curricular. Formación Universitaria, 1(3), 3-11. doi: 10.4067/S0718-50062008000300002

Díaz, F., and Hernández, G. (2002). Estrategias docentes para un aprendizaje significativo. Una interpretación constructivista. McGraw-Hill.

Díaz-Maggioli, G. (2004). Teacher-centered professional development. Association for Supervision and Curriculum Development.

Elder, L., \& Paul, R. (2008). A través de la reflexión desciframos que está mal en nuestro pensamiento. El educador: La revista de educación, 4(16), 14-15.

Ennis, R. H. (2001). Critical Thinking assessment. Theory into Practice, 2(2), 179-186.

Facione, P. A. (2007). Pensamiento Crítico: ¿Qué es y por qué es importante? https://bit. ly/2ORpa3y

Fundación COMPARTIR. (2014). Tras la excelencia docente. Cómo mejora la calidad de la educación para todos los colombianos. Panamericana Formas e Impresos S.A.

Gravett, S. (2012). Crossing the "Theory-practice Divide": Learning to Be(come) a Teacher. South African journal of childhood education, 2(2), 1-14. doi:10.4102/sajce.v2i2.9

Hargreaves, A. (1999). Hacia una geografía social de la formación docente. En J. Ángulo, J. barquín y A. Pérez (Eds.), Desarrollo profesional del docente: Política, investigación y práctica (pp. 119-145). MaterPrint, S.L.

Kim, H., Sefcik, J. S., \& Bradway, C. (2017). Characteristics of Qualitative Descriptive Studies: A Systematic Review. Research in nursing and health, 40(1), 23-42. doi. org/10.1002/nur.21768

Kegan, R. (1994). In over our heads: the mental demands of modern life. Harvard University Press.

Ledić, J. (2006). ¿Por qué invertir tiempo en el aprendizaje activo? Asociación para el Desarrollo de la Educación Superior "Universitas".

Limbach, B., \& Waugh, W. (2010). Developing higher level thinking. Journal of instructional pedagogies, 3, 1-9. 
Limbach, B., \& Waugh, W. (2014). Implementing a High-Impact, Critical Thinking process in a Learner-Centered Environment. Journal of Higher Education Theory and Practice, 14(1), 95-99.

Londoño, O., Maldonado, L., \& Calderón, L. (2016). Guía para construir estados del arte. International Corporation of Network of Knowledge (ICONK)

Miranda, C. (2003). El pensamiento crítico en docentes de educación general básica en chile: un estudio de impacto. Estudios pedagógicos (Valdivia), (29), 39-54.

Murray, T. (2009). What is the Integral in Integral Education? From Progressive Pedagogy to Integral Pedagogy. Integral review, 5(1), 1-38.

OEI. (2013). Miradas sobre la Educación en Iberoamérica. Desarrollo profesional docente y mejora de la educación. OEI.

Peko, A., \& Varga, R. (2014). Active Learning in Classrooms. Život i škola: časopis za teoriju i praksu odgoja i obrazovanja, 60(31), 59-73. https://bit.ly/30CfEXM

Rodríguez, G., Gil, J., \& García, E. (1999). Metodología de la investigación cualitativa. Ediciones Aljibe.

Rosemberg, D. (2011). Introducción. En D. Rosemberg (ed.), ¿Cómo se forma a un buen docente? (pp. 3-6). UNIPE Editorial Universitaria.

Scriven, M., \& Paul, R. (2015). Defining critical thinking. https://bit.ly/3ePSIJt

Solar, M., \& Díaz, C. (2007). El sistema de cogniciones y creencias del docente universitario y su influencia en su actuación pedagógica. Horizontes Educacionales, 12(1), 35-42.

Sternberg, R. J. (1986). Critical Thinking: Its Nature, Measurement, and Improvement. National Institute of Education.

Tamayo, O. E., Zona, R., \& Loaiza, Y. E. (2015). El pensamiento crítico en la educación. Algunas categorías centrales en su estudio. Revista Latinoamericana de Estudios Educativos, 11(2), 111-133.

Torres, A. (1996). La sistematización como investigación interpretativa crítica: entre la teoría y la práctica. Mimeo.

Torres, R. (2000). De agentes de la reforma a sujetos del cambio: La encrucijada docente en américa latina. Revista Perspectivas, 23(2), 1-21.

UNESCO (1990). Innovations and initiatives in teacher education in Asia and the Pacific region. UNESCO, Principal Regional Office for Asia and the Pacific. https://bit.ly/2WMR71c

UNESCO. (2015). La educación para todos, 2000-2015: Logros y desafíos. UNESCO.

Universidad de La Salle. (2007). Enfoque formativo lasallista. Imagen Editorial.

Universidad de La Salle. (2010). Documento institucional No. 37: La formación y el desarrollo profesional docente. CMYK Diseños e Impresos.

Uribe, O., Uribe, D., \& Vargas, M. (2017). Critical Thinking and its Importance in Education: Some Reflections. Rastros Rostros, 19(34), 78-88.doi:10.16925/ra.v19i34.2144

Vieira, I. \& Moreira, M. A. (2008). Reflective teacher education towards learner autonomy: Building a culture of possibility. In M. Raya and T. Lamb, (eds.), Pedagogy for Autonomy in Language Education: Theory, practice, and teacher education (pp. 266- 282). Authentik.

Villegas-Reimers, E. (2002). Teacher preparation: International perspective. In Encyclopedia of Education [online]. https://bit.ly/3jtzsFf 
Webber, K. L. (2012). The use of learner-centered assessment in US colleges and universities. Research in Higher Education, 53(2), 201-228. https://doi.org/10.1007/ s11162-011-9245-0

Webber, G., \& Miller, D. (2016). Progressive pedagogies and teacher education: A review of the literature. McGill journal of education, 51(3), 1061-1080.

Zohar, A., \& Lustov, E. (2018). Challenges in addressing metacognition in professional development programs in the context of instruction of higher- order thinking. In Y. Weinberger and Z. Libman (eds), Contemporary Pedagogies in Teacher Education and Development (pp. 87-96). IntechOpen.

Fecha de recepción: 25 de febrero de 2020.

Fecha de revisión: 10 de marzo de 2020.

Fecha de aceptación: 22 de septiembre de 2020. 